\title{
Adenocarcinoma of the Prostate: Future Directions for Translational Science
}

\author{
Tao Wang ${ }^{1}$ • Brian Lewis ${ }^{2} \bullet$ Ameer Elaimy $^{5}$ • Marcus Ruscetti ${ }^{2} \bullet$ \\ Mitchell Sokoloff ${ }^{3} \bullet$ Kriti Mittal $^{4} \bullet$ Thomas J. FitzGerald $^{1}$ \\ ${ }^{1}$ Department of Radiation Oncology, University of Massachusetts Medical School, \\ Worcester, MA, USA; ${ }^{2}$ Department of Molecular Cell and Cancer Biology, University \\ of Massachusetts Medical School, Worcester, MA, USA; ${ }^{3}$ Department of Urology, University \\ of Massachusetts Medical School, Worcester, MA, USA; ${ }^{4}$ Department of Hematology \\ Oncology, University of Massachusetts Medical School, Worcester, MA, USA; ${ }^{5}$ Department \\ of Medicine, University of Massachusetts Medical School, Worcester, MA, USA
}

Author for correspondence: Thomas J. FitzGerald, Department of Radiation Oncology, University of Massachusetts Medical School, Worcester, MA, USA.

Email: TJ.Fitzgerald@umassmemorial.org

Doi: https://doi.org/10.36255/exonpublications.prostatecancer.translationalscience.2021

\begin{abstract}
Adenocarcinoma of the prostate is a common malignancy affecting one in nine men, with six of every 10 cases identified in men older than 66 years, and more adversely affects African American males. It remains less common in men under the age of 40 . The age adjusted incidence is increasing with the application of prostate specific antigen (PSA) as a biomarker. PSA helps identifying the disease at an early stage, which is treatable and curable with traditional therapies. However, a significant percentage of men present with high Gleason grade and advanced disease, with lower PSA, and younger age at presentation. These patients can have a compromised outcome. Once again, we are evaluating patients under the age of 50 with advanced disease due in part to inconsistent application of clinical screening. More effort is needed for high-risk patients to
\end{abstract}

In: Prostate Cancer. Bott SRJ, Ng KL (Editors). Exon Publications, Brisbane, Australia. ISBN: 978-0-6450017-5-4; Doi: https://doi.org/10.36255/exonpublications.prostatecancer.2021

Copyright: The Authors.

License: This open access article is licenced under Creative Commons Attribution-NonCommercial 4.0 International (CC BY-NC 4.0) https://creativecommons.org/licenses/by-nc/4.0/ 
provide timely, meaningful intervention and effective therapy. In this chapter, we review the status of therapy for standard and high-risk patients, and strategies for translational science for patients at risk of compromised outcome and treatment failure.

Keywords: biomarkers; castration-resistant prostate cancer; hormone-sensitive disease; neuroendocrine expression; therapeutic resistance

\section{INTRODUCTION}

Adenocarcinoma of the prostate affects one in nine men and adversely affects African Americans (1). Local therapy including surgery and modern radiation therapy are curative, with success in low and favorable intermediate risk patients, which include more than $50 \%$ of patients who acquire the disease. This has driven a conversation of therapeutic nihilism for favorable patients. While clinical physicians have always weighed risks and benefits of therapy in juxtaposition with medical comorbidities, arguments that the impact on normal tissue by therapy outweigh the benefits of identification of the disease have become a more visible narrative promoting therapeutic nihilism and a decrease in patient screening. This has led to an increase in the identification of high-risk patients who may have benefited from earlier and more timely intervention before the disease became more advanced and less treatable/curable (2-5). Clinical colleagues continue to refine therapy techniques to decrease therapeutic morbidity including image validation of surgical margins and compressed courses of image-guided radiation therapy. In addition, improvements in systemic therapy need to be developed and applied in a timely strategic manner to improve the care of those at most extreme risk of therapy failure despite traditional therapy. These include strategies for incorporation of validated genomic and proteomic biomarkers into clinical decision care paths (6).

\section{CURRENT PATIENT MANAGEMENT}

Groups of investigators vary in the interpretation and definition of low, intermediate, and high-risk disease. For the patient at diagnosis, most study groups and national organizations consider high risk disease to be patients with PSA $>20$ at presentation with Gleason score of 8-10 and clinical stage $>=$ T3 (7). The National Comprehensive Cancer Network (NCCN) separate high risk from very high risk by T stage with T3A being high risk and T3B-T4 being very high risk (7). Other groups including the American Urological Association, the European Association of Urology, and the NRG cooperative group of the National Clinical Trials Network (NCTN) have subtle variation in criteria, nevertheless patients with more locally advanced disease, positive lymph nodes, and significant elevation in PSA with high Gleason grade are considered high risk patients (8-10). 


\section{Hormone-sensitive disease}

These patients are identified at the time of initial diagnosis or early in their disease course at the time of treatment failure. The disease almost uniformly remains responsive to hormonal therapy and nearly all forms of therapy either for local disease or oligometastatic disease as part of primary management. The application of hormone therapy is highly effective in both primary and metastatic disease (11). The challenge for patient outcome is the sequelae of hormone management applied for a protracted time period. Because of the influence of surgery/orchiectomy, the clinical application of testosterone interruption therapy was thought optimally delivered as permanent therapy $(12,13)$. With the advent of testosterone antagonist therapy, therapy did not have to be applied on a permanent basis and hormone treatment could be titrated.

\section{Hormone therapy}

Investigators were initially influenced by analogies drawn to breast cancer treatment. In breast cancer, hormone therapies are applied for years with evidence that longer duration is superior to shorter duration. Although the sequelae and limited tolerance of therapy are acknowledged, breast cancer care continues to apply hormone therapy for extended periods of time with half and full decades of treatment. The sequelae of hormone therapy in men treated for extended period for prostate cancer are visible and leave fingerprints not easily removed. There are cardiovascular, neurocognitive, and muscular-skeletal risks associated with protracted hormone therapy prompting investigators to re-visit the application of hormone therapy and to titrate the duration of hormone therapy in selected clinical situations when possible. The interruption of testosterone signaling pathways appears to have a negative impact on coronary artery health and may have a direct or indirect effect secondary to cardiovascular health on the central nervous system (14). Hormone therapy can demineralize bones and decrease muscle mass further compromising cardiovascular health (15). Hormonal therapy has both direct and indirect impact on carbohydrate metabolism resulting in increased adipose deposition, fluid retention, and weight gain creating additional challenges in maintaining both cardiovascular and muscular-skeletal health (16). The mechanism of this effect is multi-focal, however decrease in muscle mass limits storage capacity for glycogen thus promoting adipose deposition through gluconeogenesis-associated pathways. Investigators continue to evaluate the potential benefits of hormone therapy coupled with therapeutic titration (how much is enough) and different strategies.

\section{Alternative strategies}

Adequate alternatives to hormonal therapy remain an objective for translational science. The addition of hormone therapy to radiation therapy for unfavorable intermediate risk and high-risk patients has led to a survival benefit for these patients (17-18). The benefit is always balanced with therapy sequelae. Strategies for achieving the benefits without sequelae are goals for translational science 
moving forward for this patient population given the success of therapy. Our assumption has been that the mechanism of action for therapy is directly associated with testosterone interruption. This is an accepted validated mechanism; however, it is time to revisit this paradigm as alternative and additive thought processes may prove to be of additional importance. Hormone ablation therapy may function through multiple mechanisms including interruption of molecular cell adhesion pathways which play an important role in the development of tumor angiogenesis. In laboratory experiments, hormone ablation therapy appears to alter cell adhesion, preventing tumor growth and development. Although therapies directed at angiogenesis hold promise (19-21), the impact traditionally placed emphasis on altering the established tumor microvascular compartment. Strategies for cell adhesion modification placed emphasis on limiting tumor cell growth prior to the development of tumor angiogenesis. This may explain in part why cell adhesion modification with Casodex (bicalutamide) is effective because it limits tumor cell development before tumor vessels can mature (22-23). This is a possible additional benefit for radiotherapy in addition to testosterone interruption. Therefore, adhesion molecules such as integrins may be important along several steps of the angiogenesis pathway, however the most important step may be at the initiation of tumor cell adhesion. Coupled with radiation therapy, there was significant increase in tumor cell kill including in vivo tumor explants of prostate cancer cells with cell adhesion based therapeutic modulation (24-26). Therefore, strategies to apply therapy to specific tumor cell adhesion molecules, including integrin modulation, appear potentially effective in mimicking some of the impact of hormone ablation therapy but hormone signaling does many more things than simply regulate cell adhesion. Initial clinical trials using COX-2 inhibition in multiple disease areas were less successful (27-28), however, coupling cell type specific therapy with radiation treatment may help titrate hormone therapy and provide alternatives to management moving forward. If adequate alternative therapy, such as cell adhesion modulation as a co-partner with radiation therapy, can be identified, hormonal ablation therapy can be deferred to second line management as disease would be hormonesensitive and vulnerable to therapy. This would position the therapy community quite well and delay the onset of castration-resistant disease secondary to chronic application of hormone treatment. Alternative strategies including the use of novel androgen receptor signaling inhibition with agents such as abiraterone acetate and enzalutamide may also hold promise in early phase hormone sensitive disease as an alternative to Lupron and other current hormone application strategies $(29,30)$.

\section{Radiation therapy}

Improvements in radiation therapy technology have provided significant advances in patient care. Therapy can now be applied in high doses in a safe manner through intensity modulation and daily image guidance which is both nimble and accurate. Using volume modulated arc therapy, concerns of intra-fractional motion of targets are eased due to the speed of treatment with therapy now delivered in a few minutes once targets have been confirmed with image guidance (31). 
Investigators are now delivering higher daily treatment dose to targets due in large part to the confidence in daily treatment reproducibility and accuracy in normal tissue avoidance (32-33). In the past, hormone therapy was thought to be an excellent adjunct to care, perhaps in part to limitations in therapy technology. Coupled with modern imaging and improvements in image tracers for PET including therapeutic application of radio pharmacy, radiation therapy may evolve into the initial sole modality of care with hormone and hormone-associated analog therapy moved to second line management, even for hormone-sensitive disease (5).

\section{Hormone-resistance disease}

Although nearly all patients respond to hormone androgen deprivation therapy, over time patients with metastatic disease and protracted hormone therapy ultimately develop castration-resistant disease refractory to more traditional therapies. Although prostate cancers historically metastasize to bone as a preferred site of disease, clinicians are now seeing soft tissue disease including end organ parenchyma and the central nervous system (34-37). This may be in part driven by alteration of the bone marrow environment by protracted hormonal application thus generating alteration in soft tissue parenchymal microenvironment promoting tumor growth. This may also be due to the propensity of tumors that undergo treatment-induced neuroendocrine differentiation to metastasize to visceral organs such including the liver (37). The development of this situation is accompanied in parallel by an accumulation of various gene mutations, chromosomal translocations, and increased aberrant DNA repair mechanisms and lineage plasticity within the tumor population that permit the hormone insensitive cells to thrive and proliferate (38-39). These tumors have a predilection to express homologous recombination genes independent of processes associated with repair, therefore more vulnerable to mutations and malevolent clinical behavior. This population of patients continue to have guarded outcome, therefore a real opportunity for improvement in clinical care. In addition, patients with alterations in DNA repair pathways may respond better to immunotherapies due to a higher mutational load. Application of androgen receptor directed therapies in the early phase of castrate resistance can generate a response to therapy, however, the response is not uniformly durable, therefore alternate strategies need to be developed (29).

\section{Tumor metabolism}

Tumor metabolism pathways are also altered in advanced prostate cancer. Pathways supporting glycolysis appear promoted in prostate tumor cells. Among potentially important pathways includes fructose-biphosphate aldose A (ALDOA). Aldolase A is encoded by ALDOA and is an important enzyme on the glycolysis pathway. Recent evidence suggests that ALDOA is an oncogene and upregulation of it is associated with prostate cancer growth, metastasis, and poor survival. This raises the potential of a metabolic target for prostate cancer care moving forward (40). 


\section{Androgen and androgen receptors}

Androgen signaling drives prostate cancer development and disease progression and is thought to be responsible for inducing pathways towards castration resistant disease. The androgen receptor functions as a transcription factor and activates downstream signaling associated with disease progression which is interrupted by androgen deprivation therapy. Endogenous androgens include testosterone and dihydrotestosterone. Even in their absence, resistance can develop, and hormone therapy becomes ineffective even though the androgen signaling pathways remain active (41). Alterations in the androgen receptor have been identified which are potentially responsible or work in parallel to the development of castrate resistant disease. An initial example of alteration was the identification of additional $\mathrm{X}$ chromosome copy numbers in the AR gene locus in patients with castrate resistant disease $(42,43)$. Translational science has identified AR phosphorylation sites/ kinase function which are thought to maintain transcriptional activity in this setting including the generation of altered binding sites (44). It is thought that hypoxia inducible factor (HIF) functions through this mechanism. In the absence of oxygen, HIF is activated, translocated to the nucleus, and activates genes associated with invasion and tumor cell survival (45). Expression of HIF is associated with poor prognosis in patients with prostate cancer as ADT in hypoxia is thought to induce adaptive androgen/AR therapeutic independence, thus invite resistance to therapy (46).

\section{Activated kinase}

Activated kinase activity is also thought to play an important role in castrateresistant disease (47). Therefore, modern transcriptomic profiling can be applied to tissue of patients with known castrate-resistant disease to see if repetitive common pathways can be identified to define actionable targets for application of therapy. Investigators have identified in tissue samples of patients with castrateresistant prostate cancer amplification of extracellular signal-regulated kinase 1 (ERK1) in a large cohort of patients $(48,49)$. Elevated levels of phosphorylated ERK1 and ERK2 have been found in tissue samples of patients who were with high-risk features post prostatectomy and outcome were aligned with ERK expression more than clinicopathological features (50). Therefore, identifying both appropriate patients and targets that align with expression products are needed to improve outcomes. Approved therapies such as Trametinib may be applicable in this setting. In our laboratory, we have identified subsets of cell lines resistant to radiation therapy which can be made more sensitive to treatment with down regulation of ERK 1 and 2 (51).

\section{Neuroendocrine and resistance to therapeutics}

Neuroendocrine features are now being identified in prostate cancer and they impose a guarded clinical outcome (52-54). The neuroendocrine cells are found to increase in prostate adenocarcinoma (55-57). The expansion of NE cells in prostate cancer may be derived from preexisting NE cells in the normal or 
neoplastic prostate cells $(58,59)$, or from treatment-induced differentiation (6064). Neuroendocrine progenitor cells are a limited percentage of epithelial cells and reside in all anatomical zones of the prostate gland. They have limited proliferative potential and are devoid of the androgen receptor with limited to no capacity to generate PSA (55). The neuroendocrine cells contain neurosecretory granules and express neural peptide hormones including bombesin/gastrin secreting releasing peptide (GRP), neurotensin (NT), serotonin, calcitonin, and parathyroid hormone related peptide (PTHrP) (65). These cells express survival genes including Bcl-2. In our laboratory, we have identified modified cell lines that demonstrate resistance to radiation therapy. These cells interestingly demonstrate the ability to undergo epithelial-mesenchymal transition. These cells can be made sensitive to treatment with down regulation of $\mathrm{Bcl}-2(65,66)$.

\section{Poly (ADP-ribose) polymerase}

It is important to develop pathways of therapy that are independent of hormonerelated signaling strategies. A potential area of improvement is the use of poly (ADP-ribose) polymerase (PARP) inhibitors. These compounds impact DNA base excision repair, transcription, replication, genomic stability, and cell death $(67,68)$. Because of their impact generated in the background of fundamental basic science, PARP inhibition holds promise in multiple disease sites including prostate cancer (69-71). One of the involved mechanisms is the mammalian target of rapamycin pathway (mTOR) (72). While PARP-1 activation may promote tumor cell growth, inhibition of PARP inhibits tumor growth and promotes cell death particularly when defect of other genes such as BRCA1 and BRCA2 or ATM (Ataxia-telangiectasia mutated) exist $(73,74)$. Inhibition of PARP in malignancy with BRCA1 and BRCA2 mutations shows convergence of AR signaling pathways and DNA damage response. Down-regulating homologous recombination genes in castrate-resistant tumor with AR-directed therapy may serve to further sensitize tumor to PARP inhibition as a two-step process including both therapies (75). Early clinical trials are favorable in selected patients who have homozygous deletions, deleterious mutations, or both, in BCRA 1/2, ATM (Fanconi) and CHEK2, identified using next generation sequencing in castrate-resistant patients including those who had received previous therapy including docetaxel $(76,77)$. The next generation of PARP inhibitors are demonstrating response is previously treated patients (78). In our laboratory, we have identified cell lines resistant to radiation therapy that can be made more sensitive to treatment with the addition of PARP inhibitors, therefore a potentially promising addition to the care of highrisk patients.

\section{Immunotherapy}

Cellular immunotherapy with sipuleucel-T has been applied to patients with metastatic castrate resistant prostate cancer (79). Though the first ever FDA-approved immunotherapy, Sipuleucel-T, was approved in the setting of castration resistance prostate cancer (albeit only mediating a moderate delay in mortality) (80), other now conventional cell-based (for example, chimeric antigen receptor [CAR]-T 
cells) and checkpoint blockade immunotherapies (for example, PD-1/PD-L1, CTLA-4 antibodies) that have revolutionized the treatment of other malignancies have yet to be effective or approved in the setting of prostate cancer $(81,82)$. This is possibly a consequence of the immunologically "cold" landscape of prostate cancer that is devoid of cytotoxic T lymphocytes and infiltrated with immunosuppressive myeloid cell populations. Combining immunotherapeutic agents with other approved therapies for castration-resistance prostate cancer, however, appears to be a promising strategy and is currently under investigation (83). Patients with alterations in DNA repair genes may respond better to immunotherapies due to a higher tumor mutational burden and combining immune checkpoint blockade with PARP inhibitors may further improve the treatment outlook of this subset of castration resistance prostate cancer patients. Release of tumor antigens and immunostimulatory molecules following radiation-induced cell death may also boost the impact of immunotherapy regimens by increasing tumor immunogenicity (84-86). In addition, therapies that indirectly (for example, chemotherapies) or directly (for example, CSF1-R, CCL2 antagonists) target suppressive myeloid populations could further enhance $\mathrm{T}$ cell function and as a result immunotherapy efficacy.

\section{Imaging and theranostics}

Improvements in imaging are playing an important role in patient management for prostate cancer. Magnetic resonance imaging is fused into ultrasound to provide accuracy in biopsy, identify aggregates of disease including extraprostatic extension of disease, involvement of the neurovascular bundle, and potentially identify areas of high-risk disease less obvious in a background of low-risk disease (86). This has considerable influence in the planning of radiation therapy and moves patients with higher risk to radiation therapy as opposed to surgery for primary management. In addition, this has served to improve the accuracy of radiation therapy including brachytherapy both in planning and daily execution of therapy. Metabolic imaging with Axumin (fluciclovine PET/CT scan) (87) and PSMA PET/CT scan (88) is teaching us more accurate location of lymph node anatomy further improving the accuracy of radiation therapy. Further improvements in imaging with respect to identification of disease and response to therapy will be discussed in the section on hormone resistant disease.

The Radiographic Assessments for detection of Advanced Recurrence (RADAR) Groups 1 and 2 have identified fundamental elements of imaging of prostate cancer including technetium bone scan, magnetic resonance imaging, and computer tomography $(89,90)$. In the group 2 review, important aspects of next generation imaging (NGI) with novel PET radioligands were identified as being important next steps for both imaging disease and possibly being used as vehicles for therapy as these strategies mature for the application of radiopharmacy (89). Imaging with bone scintigraphy with technetium-labeled poly phosphates and diphosphates (Tc 99/Tc MDP) is a well-established imaging strategy for both identification of bone metastasis and evaluating response and/or disease progression. Alpha emitting Radium 223 has been used to treat 
bone metastasis. The breakdown product of Radium is strontium which is deposited in bone and subsequently affects bone metastasis as a secondary indirect event (91).

Prostate specific membrane antigen (PSMA) has emerged as an important biomarker for prostate cancer management and may serve an important role for both imaging and the emerging field of theranostics combining imaging and infusional radiation therapy (92). Technetium is a bone-seeking isotope active in areas of new bone formation, therefore identifying areas of tumor in an indirect manner as disease promotes new bone formation as a response to injury $(93,94)$. In adults, new bone formation can be associated with degenerative bony changes or metastatic disease, however in context the test is helpful in evaluating potential areas of metastatic disease. F-Na-18 fluoride can be applied with PET to identify bone metastasis similar to technetium and may also provide a quantitative basis for measuring the volume of disease in bone because of three-dimensional volumetrics (95). The challenge for these compounds is they only measure disease in bone. Given the changes in pattern of care moving forward including failure and disease progression in soft tissue, imaging vehicles of the future will require strategies for imaging all sites of disease for quantification of the volume of disease and response assessment. F18-fluciclovine (F18-FACBC) images protein synthesis and can be applied with PET CT and PET MR (96). This can image prostate recurrence without significant uptake in the bladder and has the potential of providing quantitative metrics for the volume of disease. F18/Cl1-Choline and C13-acetate both target phospholipid synthesis (97). Both can identify recurrence of disease and provide quantitative metrics. Bladder accumulation and short half-life of $\mathrm{C} 13$ acetate can limit utility of clinical application. PSMA-targeting agents have been developed with imaging using SPECT-CT and PET-CT which can be applied for imaging of recurrence and possibly therapy $(98,99)$. Serial imaging with SPECT may be used moving forward with image fusion to perform quantitative dosimetry. Dose to target volume as well as dose migration to unintended sites can calculate dose to target in a manner similar to teletherapy and brachytherapy and use radiosurgery to augment dose to target as needed for treatment of oligometastasis. This approach would be used by replacing the radionucleotide Ga 68 with either a beta emitting nuclide such as lutetium 177 (Lui 177) or an alpha emitter such as actinium 225 (Ac 225 or bismuth 213 (Bi 213) (100). Alpha emitters may have a theoretical advantage as tumoricidal effects may be independent of both cell cycle and the oxygen effect (100). Early trials with AC 225 have demonstrated response in patients with castrate resistant prostate disease with xerostomia as the primary point of toxicity due to accumulation of isotope in salivary tissue. The alpha particle therapy appears more effective in chemotherapy naïve disease. Therefore, the future may include the application of tools for both imaging and therapy through similar processes with imaging used to both identify disease and assess dose to volume using stereotactic therapy to augment dose to areas of limited uptake. Through this prism the radiation oncology/radiology partnership may provide the upfront "chemotherapy" (systemic therapy) of the future. 


\section{Adjunct treatment:}

Androgen deplete therapy

Theranostics

\section{Cheomotherapy}

Inhibitor/Target therapy

\section{$\notin$ \\ Radiotherapy

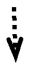

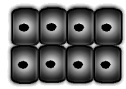

Tumor

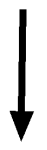

0

Survived cell
Molecular mechanisms:

HIF-1 $\alpha$ pathway

DNA repair: PARP...

Apoptosis, Necrosis...

Surface receptors: Ingetrin, EGFR...

Kinases: ERK, mTOR...

Immunotherapy

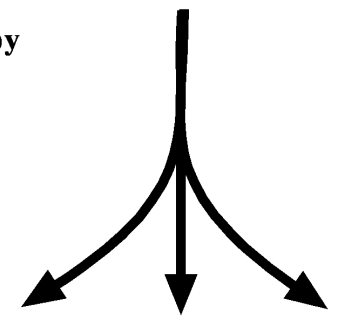

AR and signaling

EMT signaling

Epigenetics

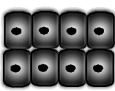

Regrowth

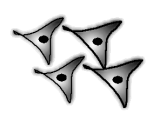

Metastasis

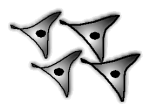

Differentiation

Figure 1. Therapeutic strategies associated with molecular mechanisms of prostate cancer cell survival upon ionizing radiation. Cells less sensitive to therapy will survive after being treated with radiation therapy. The schematic chart suggests the possible molecular mechanisms associated with tumor cell survival. With the modern development of imaging tools, hormone ablation therapy, target therapy, chemotherapy, immunotherapy and radiopharmacy, effective therapeutic strategies will evolve for the treatment of high-risk patients.

\section{CONCLUSION}

Molecular science of prostate cancer has matured at a rapid rate and direct applications of our growing knowledge are now on the horizon. Application of protocols to modulate cell adhesions, signaling pathways, survival pathways, epigenetic, DNA repair and hypoxia conditions or immunotherapy may prove to be important adjuncts in the clinical RT management of these patients (Figure 1). The success of therapies for low and intermediate risk may permit titration of 
therapy adjusted to the sequelae of current management. For the high-risk patient, advances in our understanding of genomics/proteomics coupled with better understanding of molecular science will serve to improve outcome of high-risk patients affected with disease.

Conflict of Interest: The authors declare no potential conflicts of interest with respect to research, authorship and/or publication of this chapter.

Copyright and Permission Statement: The authors confirm that the materials included in this chapter do not violate copyright laws. Where relevant, appropriate permissions have been obtained from the original copyright holder(s), and all original sources have been appropriately acknowledged or referenced.

\section{REFERENCES}

1. Siegel RL, Miller KD, Jemal A. Cancer statistics, 2020. CA Cancer J Clin. 2020;70:7-30. https://doi. org/10.3322/caac. 21590

2. Rosenthal SA, Hu C, Sartor O, Gomella LG, Amin MB, Purdy J, et al. Effect of Chemotherapy With Docetaxel With Androgen Suppression and Radiotherapy for Localized High-Risk Prostate Cancer: The Randomized Phase III NRG Oncology RTOG 0521 Trial. J Clin Oncol. 2019;37:1159-68. https:// doi.org/10.1200/JCO.18.02158

3. Spratt DE, Zhang J, Santiago-Jimenez M, Dess RT, Davis JW, Den RB, et al. Development and Validation of a Novel Integrated Clinical-Genomic Risk Group Classification for Localized Prostate Cancer. J Clin Oncol. 2018;36:581-90. https://doi.org/10.1200/JCO.2017.74.2940

4. Nguyen PL, Martin NE, Choeurng V, Palmer-Aronsten B, Kolisnik T, Beard CJ, et al. Utilization of biopsy-based genomic classifier to predict distant metastasis after definitive radiation and short-course ADT for intermediate and high-risk prostate cancer. Prostate Cancer Prostatic Dis. 2017;20:186-92. https://doi.org/10.1038/pcan.2016.58

5. Shipley WU, Seiferheld W, Lukka HR, Major PP, Heney NM, Grignon DJ, et al. Radiation with or without Antiandrogen Therapy in Recurrent Prostate Cancer. N Engl J Med. 2017;376:417-28. https:// doi.org/10.1056/NEJMoal607529

6. Tosoian JJ, Birer SR, Jeffrey Karnes R, Zhang J, Davicioni E, Klein EE, et al. Performance of clinicopathologic models in men with high risk localized prostate cancer: impact of a 22-gene genomic classifier. Prostate Cancer Prostatic Dis. 2020;23:646-53. https://doi.org/10.1038/s41391-020-0226-2

7. Mohler JL, Armstrong AJ, Bahnson RR, D'Amico AV, Davis BJ, Eastham JA, et al. Prostate Cancer, Version 1.2016. J Natl Compr Canc Netw. 2016;14:19-30.

8. Gleason DF, Group. TVUR. Histologic grading and staging of prostatic carcinoma. In: Tannenbaum M, editor. Urologic Pathology. Philadelphia, PA: Lea \& Febiger; 1997. p. 171-87.

9. Edge SB, Byrd DR, Compton CC, Fritz AG, Greene FL, Trotti A. AJCC Cancer Staging Manual. 7th ed. New York, NY: Springer; 2010.

10. Cooperberg MR, Hilton JF, Carroll PR. The CAPRA-S score: A straightforward tool for improved prediction of outcomes after radical prostatectomy. Cancer. 2011;117:5039-46. https://doi.org/10.1002/ cncr.26169

11. Mahler C, VerhelstJ, Denis L. Clinical pharmacokinetics of the antiandrogens and their efficacy in prostate cancer. Clin Pharmacokinet. 1998;34:405-17. https://doi.org/10.2165/00003088-199834050-00005

12. Machtens S, Schultheiss D, Kuczyk M, Truss MC, Jonas U. The history of endocrine therapy of benign and malignant diseases of the prostate. World J Urol. 2000;18:222-6. https://doi.org/10.1007/ s003450000120 
13. Granfors T, Modig H, Damber JE, Tomic R. Long-term followup of a randomized study of locally advanced prostate cancer treated with combined orchiectomy and external radiotherapy versus radiotherapy alone. J Urol. 2006;176:544-7. https://doi.org/10.1016/j.juro.2006.03.092

14. Saigal CS, Gore JL, Krupski TL, Hanley J, Schonlau M, Litwin MS, et al. Androgen deprivation therapy increases cardiovascular morbidity in men with prostate cancer. Cancer. 2007;110:1493-500. https:// doi.org/10.1002/cncr.22933

15. Maillefert JF, Sibilia J, Michel F, Saussine C, Javier RM, Tavernier C. Bone mineral density in men treated with synthetic gonadotropin-releasing hormone agonists for prostatic carcinoma. J Urol. 1999;161:1219-22. https://doi.org/10.1016/S0022-5347(01)61639-2

16. Saylor PJ, Smith MR. Adverse effects of androgen deprivation therapy: defining the problem and promoting health among men with prostate cancer. J Natl Compr Canc Netw. 2010;8:211-23. https:// doi.org/10.6004/jnccn.2010.0014

17. Wo JY, Zietman AL. Why does androgen deprivation enhance the results of radiation therapy? Urol Oncol. 2008;26:522-9. https://doi.org/10.1016/j.urolonc.2008.03.008

18. Schmidt-Hansen M, Hoskin P, Kirkbride P, Hasler E, Bromham N. Hormone and radiotherapy versus hormone or radiotherapy alone for non-metastatic prostate cancer: a systematic review with metaanalyses. Clin Oncol (R Coll Radiol). 2014;26:e21-46. https://doi.org/10.1016/j.clon.2014.06.016

19. Garcia-Barros M, Paris F, Cordon-Cardo C, Lyden D, Rafii S, Haimovitz-Friedman A, et al. Tumor response to radiotherapy regulated by endothelial cell apoptosis. Science. 2003;300:1155-9. https:// doi.org/10.1126/science.1082504

20. Bergers G, Javaherian K, Lo KM, Folkman J, Hanahan D. Effects of angiogenesis inhibitors on multistage carcinogenesis in mice. Science. 1999;284:808-12. https://doi.org/10.1126/science.284.5415.808

21. Jimenez JA, Kao C, Raikwar S, Gardner TA. Current status of anti-angiogenesis therapy for prostate cancer. Urol Oncol. 2006;24:260-8. https://doi.org/10.1016/j.urolonc.2005.11.022

22. Lee EC, Zhan P, Schallhom R, Packman K, Tenniswood M. Antiandrogen-induced cell death in LNCaP human prostate cancer cells. Cell Death Differ. 2003;10:761-71. https://doi.org/10.1038/ sj.cdd. 4401228

23. Wang T, Alavian MR, Goel HL, Languino LR, Fitzgerald TJ. Bicalutamide inhibits androgen-mediated adhesion of prostate cancer cells exposed to ionizing radiation. Prostate. 2008;68:1734-42. https:// doi.org/10.1002/pros.20838

24. Wang T, Huang J, Vue M, Alavian MR, Goel HL, Altieri DC, et al. alphavbeta3 Integrin Mediates Radioresistance of Prostate Cancer Cells Through Regulation of Survivin. Mol Cancer Res. 2018. https://doi.org/10.1158/1541-7786.MCR-18-0544

25. Goel HL, Sayeed A, Breen M, Zarif MJ, Garlick DS, Leav I, et al. betal integrins mediate resistance to ionizing radiation in vivo by inhibiting c-Jun amino terminal kinase 1. J Cell Physiol. 2013;228: 1601-9. https://doi.org/10.1002/jcp.24323

26. Eke I, Makinde AY, Aryankalayil MJ, Reedy JL, Citrin DE, Chopra S, et al. Long-term Tumor Adaptation after Radiotherapy: Therapeutic Implications for Targeting Integrins in Prostate Cancer. Mol Cancer Res. 2018;16:1855-64. https://doi.org/10.1158/1541-7786.MCR-18-0232

27. Edelman MJ, Watson D, Wang X, Morrison C, Kratzke RA, Jewell S, et al. Eicosanoid modulation in advanced lung cancer: cyclooxygenase-2 expression is a positive predictive factor for celecoxib + chemotherapy--Cancer and Leukemia Group B Trial 30203. J Clin Oncol. 2008;26:848-55. https:// doi.org/10.1200/JCO.2007.13.8081

28. Midgley RS, McConkey CC, Johnstone EC, Dunn JA, Smith JL, Grumett SA, et al. Phase III randomized trial assessing rofecoxib in the adjuvant setting of colorectal cancer: final results of the VICTOR trial. J Clin Oncol. 2010;28:4575-80. https://doi.org/10.1200/JCO.2010.29.6244

29. Wang T, Languino LR, Lian J, Stein G, Blute M, Fitzgerald TJ. Molecular targets for radiation oncology in prostate cancer. Front Oncol. 2011;1:17. https://doi.org/10.3389/fonc.2011.00017

30. Lu H, Wang T, Li J, Fedele C, Liu Q, Zhang J, et al. alphavbeta6 Integrin Promotes CastrateResistant Prostate Cancer through JNKl-Mediated Activation of Androgen Receptor. Cancer Res. 2016;76:5163-74. https://doi.org/10.1158/0008-5472.CAN-16-0543

31. Teoh M, Clark CH, Wood K, Whitaker S, Nisbet A. Volumetric modulated arc therapy: a review of current literature and clinical use in practice. Br J Radiol. 2011;84:967-96. https://doi.org/10.1259/ bjr/22373346 
32. van Herk M. Errors and margins in radiotherapy. Semin Radiat Oncol. 2004;14:52-64. https://doi. org/10.1053/j.semradonc.2003.10.003

33. Jaffray D, Kupelian P, Djemil T, Macklis RM. Review of image-guided radiation therapy. Expert Rev Anticancer Ther. 2007;7:89-103. https://doi.org/10.1586/14737140.7.1.89

34. Craig J, Woulfe J, Sinclair J, Malone S. Isolated brain metastases as first site of recurrence in prostate cancer: case report and review of the literature. Curr Oncol. 2015;22:e493-7. https://doi.org/10.3747/ co. 22.2542

35. Kume H, Takai K, Kameyama S, Kawabe K. Multiple pulmonary metastasis of prostatic carcinoma with little or no bone or lymph node metastasis. Report of two cases and review of the literature. Urol Int. 1999;62:44-7. https://doi.org/10.1159/000030355

36. Reinstatler L, Dupuis J, Dillon JL, Black CC, Phillips JD, Hyams ES. Lung malignancy in prostate cancer: A report of both metastatic and primary lung lesions. Urol Case Rep. 2018;16:119-22. https:// doi.org/10.1016/j.eucr.2017.11.027

37. Pouessel D, Gallet B, Bibeau F, Avances C, Iborra F, Senesse P, et al. Liver metastases in prostate carcinoma: clinical characteristics and outcome. BJU Int. 2007;99:807-11. https://doi. org/10.1111/j.1464-410X.2006.06663.x

38. Jin JK, Dayyani F, Gallick GE. Steps in prostate cancer progression that lead to bone metastasis. Int J Cancer. 2011;128:2545-61. https://doi.org/10.1002/ijc.26024

39. Clarke NW, Hart CA, Brown MD. Molecular mechanisms of metastasis in prostate cancer. Asian J Androl. 2009;11:57-67. https://doi.org/10.1038/aja.2008.29

40. Heron PW, Abellan-Flos M, Salmon L, Sygusch J. Bisphosphonate Inhibitors of Mammalian Glycolytic Aldolase. J Med Chem. 2018;61:10558-72. https://doi.org/10.1021/acs.jmedchem.8b01000

41. Chandrasekar T, Yang JC, Gao AC, Evans CP. Mechanisms of resistance in castration-resistant prostate cancer (CRPC). Transl Androl Urol. 2015;4:365-80.

42. Spencer JA, Watson JM, Lubahn DB, Joseph DR, French FS, Wilson EM, et al. The androgen receptor gene is located on a highly conserved region of the $\mathrm{X}$ chromosomes of marsupial and monotreme as well as eutherian mammals. J Hered. 1991;82:134-9. https://doi.org/10.1093/oxfordjournals.jhered. al11047

43. Edwards J, Krishna NS, Grigor KM, Bartlett JM. Androgen receptor gene amplification and protein expression in hormone refractory prostate cancer. Br J Cancer. 2003;89:552-6. https://doi.org/ 10.1038/sj.bjc. 6601127

44. Gioeli D, Ficarro SB, Kwiek JJ, Aaronson D, Hancock M, Catling AD, et al. Androgen receptor phosphorylation. Regulation and identification of the phosphorylation sites. J Biol Chem. 2002;277: 29304-14. https://doi.org/10.1074/jbc.M204131200

45. Bhandari V, Hoey C, Liu LY, Lalonde E, Ray J, Livingstone J, et al. Molecular landmarks of tumor hypoxia across cancer types. Nat Genet. 2019;51:308-18. https://doi.org/10.1038/s41588-018-0318-2

46. Al-Ubaidi FL, Schultz N, Egevad L, Granfors T, Helleday T. Castration therapy of prostate cancer results in downregulation of HIF-lalpha levels. Int J Radiat Oncol Biol Phys. 2012;82:1243-8. https:// doi.org/10.1016/j.ijrobp.2011.10.038

47. Inoue $\mathrm{T}$, Ogawa $\mathrm{O}$. Role of signaling transduction pathways in development of castration-resistant prostate cancer. Prostate Cancer. 2011;2011:647987. https://doi.org/10.1155/2011/647987

48. Nickols NG, Nazarian R, Zhao SG, Tan V, Uzunangelov V, Xia Z, et al. MEK-ERK signaling is a therapeutic target in metastatic castration resistant prostate cancer. Prostate Cancer Prostatic Dis. 2019;22:531-8. https://doi.org/10.1038/s41391-019-0134-5

49. Rodriguez-Berriguete G, Fraile B, Martinez-Onsurbe P, Olmedilla G, Paniagua R, Royuela M. MAP Kinases and Prostate Cancer. J Signal Transduct. 2012;2012:169170. https://doi.org/10.1155 /2012/169170

50. Ciccarelli C, Di Rocco A, Gravina GL, Mauro A, Festuccia C, Del Fattore A, et al. Disruption of MEK/ ERK/c-Myc signaling radiosensitizes prostate cancer cells in vitro and in vivo. J Cancer Res Clin Oncol. 2018;144:1685-99. https://doi.org/10.1007/s00432-018-2696-3

51. Wang T, Carraway RE, LeRoche D, FitzGerald TJ. Disruption of ERKl/2 sensitizes radiation resistance prostate cancer cells to paclitaxel and ionizing radiation. International J of Radiation Oncology, Biology and Physics. 2014;90:S806. https://doi.org/10.1016/j.ijrobp.2014.05.2326 
52. Huang J, Yao JL, di Sant'Agnese PA, Yang Q, Bourne PA, Na Y. Immunohistochemical characterization of neuroendocrine cells in prostate cancer. Prostate. 2006;66:1399-406. https://doi.org/10.1002/ pros. 20434

53. Davies A, Zoubeidi A, Selth LA. The epigenetic and transcriptional landscape of neuroendocrine prostate cancer. Endocr Relat Cancer. 2020;27:R35-R50. https://doi.org/10.1530/ERC-19-0420

54. Krauss DJ, Hayek S, Amin M, Ye H, Kestin LL, Zadora S, et al. Prognostic significance of neuroendocrine differentiation in patients with Gleason score 8-10 prostate cancer treated with primary radiotherapy. Int J Radiat Oncol Biol Phys. 2011;81:el19-25. https://doi.org/10.1016/j.ijrobp.2010.12.064

55. Bonkhoff H. Neuroendocrine differentiation in human prostate cancer. Morphogenesis, proliferation and androgen receptor status. Ann Oncol. 2001;12 Suppl 2:S141-4. https://doi.org/10.1093/ annonc/12.suppl_2.S141

56. Mosca A, Berruti A, Russo L, Torta M, Dogliotti L. The neuroendocrine phenotype in prostate cancer: basic and clinical aspects. J Endocrinol Invest. 2005;28:141-5.

57. Nelson EC, Cambio AJ, Yang JC, Ok JH, Lara PN, Jr., Evans CP. Clinical implications of neuroendocrine differentiation in prostate cancer. Prostate Cancer Prostatic Dis. 2007;10:6-14. https://doi. org/10.1038/sj.pcan.4500922

58. Yuan TC, Veeramani S, Lin MF. Neuroendocrine-like prostate cancer cells: neuroendocrine transdifferentiation of prostate adenocarcinoma cells. Endocr Relat Cancer. 2007;14:531-47. https://doi. org/10.1677/ERC-07-0061

59. Martin-Orozco RM, Almaraz-Pro C, Rodriguez-Ubreva FJ, Cortes MA, Ropero S, Colomer R, et al. EGF prevents the neuroendocrine differentiation of LNCaP cells induced by serum deprivation: the modulator role of PI3K/Akt. Neoplasia. 2007;9:614-24. https://doi.org/10.1593/neo.07337

60. Conteduca V, Burgio SL, Menna C, Carretta E, Rossi L, Bianchi E, et al. Chromogranin A is a potential prognostic marker in prostate cancer patients treated with enzalutamide. Prostate. 2014;74:1691-6. https://doi.org/10.1002/pros.22890

61. Berruti A, Mosca A, Tucci M, Terrone C, Torta M, Tarabuzzi R, et al. Independent prognostic role of circulating chromogranin A in prostate cancer patients with hormone-refractory disease. Endocr Relat Cancer. 2005;12:109-17. https://doi.org/10.1677/erc.1.00876

62. Sciarra A, Gentile V, Monti S, Mariotti G, Pastore A, Di Silverio F. Variation of chromogranin A serum levels after radical retropubic prostatectomy for prostate adenocarcinoma. Arch Androl. 2003;49: 39-48. https://doi.org/10.1080/01485010390129160

63. Sarkar D, Singh SK, Mandal AK, Agarwal MM, Mete UK, Kumar S, et al. Plasma chromogranin A: clinical implications in patients with castrate resistant prostate cancer receiving docetaxel chemotherapy. Cancer Biomark. 2010;8:81-7. https://doi.org/10.3233/CBM-2011-0198

64. Deng X, Elzey BD, Poulson JM, Morrison WB, Ko SC, Hahn NM, et al. Ionizing radiation induces neuroendocrine differentiation of prostate cancer cells in vitro, in vivo and in prostate cancer patients. Am J Cancer Res. 2011;1:834-44.

65. Vashchenko N, Abrahamsson PA. Neuroendocrine differentiation in prostate cancer: implications for new treatment modalities. Eur Urol. 2005;47:147-55. https://doi.org/10.1016/j.eururo.2004.09.007

66. Wang T, Carraway RE, Briggs J, Chen H, FitzGerald TJ. Down-regulation of Bcl2 sensitizes radiation resistance prostate cancer cells to ionizing radiation. Program and Proceedings in Molecular Targets and Cancer Therapeutics. 2013;AACR-NCI-EORTC International Conference, Boston, MA:345. https://doi.org/10.1158/1535-7163.TARG-13-C50

67. Ellisen LW. PARP inhibitors in cancer therapy: promise, progress, and puzzles. Cancer Cell. 2011;19:165-7. https://doi.org/10.1016/j.ccr.2011.01.047

68. Pitroda SP, Pashtan IM, Logan HL, Budke B, Darga TE, Weichselbaum RR, et al. DNA repair pathway gene expression score correlates with repair proficiency and tumor sensitivity to chemotherapy. Sci Transl Med. 2014;6:229ra42. https://doi.org/10.1126/scitranslmed.3008291

69. Lord CJ, Ashworth A. The DNA damage response and cancer therapy. Nature. 2012;481:287-94. https://doi.org/10.1038/nature 10760

70. Castro E, Mateo J, Olmos D, de Bono JS. Targeting DNA Repair: The Role of PARP Inhibition in the Treatment of Castration-Resistant Prostate Cancer. Cancer J. 2016;22:353-6. https://doi.org/10.1097/ PPO.0000000000000219 
71. Mateo J, Carreira S, Sandhu S, Miranda S, Mossop H, Perez-Lopez R, et al. DNA-Repair Defects and Olaparib in Metastatic Prostate Cancer. N Engl J Med. 2015;373:1697-708. https://doi.org/10.1056/ NEJMoal506859

72. Wang G, Zhao D, Spring DJ, DePinho RA. Genetics and biology of prostate cancer. Genes Dev. 2018;32:1105-40. https://doi.org/10.1101/gad.315739.118

73. Lloyd RL, Wijnhoven PWG, Ramos-Montoya A, Wilson Z, Illuzzi G, Falenta K, et al. Combined PARP and ATR inhibition potentiates genome instability and cell death in ATM-deficient cancer cells. Oncogene. 2020;39:4869-83. https://doi.org/10.1038/s41388-020-1328-y

74. Farmer H, McCabe N, Lord CJ, Tutt AN, Johnson DA, Richardson TB, et al. Targeting the DNA repair defect in BRCA mutant cells as a therapeutic strategy. Nature. 2005;434:917-21. https://doi. org/10.1038/nature03445

75. Asim M, Tarish F, Zecchini HI, Sanjiv K, Gelali E, Massie CE, et al. Synthetic lethality between androgen receptor signalling and the PARP pathway in prostate cancer. Nat Commun. 2017;8:374. https:// doi.org/10.1038/s41467-017-00393-y

76. Christenson ES, Antonarakis ES. PARP inhibitors for homologous recombination-deficient prostate cancer. Expert Opin Emerg Drugs. 2018;23:123-33. https://doi.org/10.1080/14728214.2018.1459563

77. Hiew K, Hart CA, Ali A, Elliott T, Ramani V, Sangar V, et al. Primary Mutational Landscape Linked with Pre-Docetaxel Lactate Dehydrogenase Levels Predicts Docetaxel Response in Metastatic CastrateResistant Prostate Cancer. Eur Urol Focus. 2019;5:831-41. https://doi.org/10.1016/j.euf.2018.04.006

78. Hussain M, Mateo J, Fizazi K, Saad F, Shore N, Sandhu S, et al. Survival with Olaparib in Metastatic Castration-Resistant Prostate Cancer. N Engl J Med. 2020;383:2345-57. https://doi.org/10.1056/ NEJMoa2022485

79. Kawalec P, Paszulewicz A, Holko P, Pilc A. Sipuleucel-T immunotherapy for castration-resistant prostate cancer. A systematic review and meta-analysis. Arch Med Sci. 2012;8:767-75. https://doi. org/10.5114/aoms.2012.31610

80. Kantoff PW, Higano CS, Shore ND, Berger ER, Small EJ, Penson DF, et al. Sipuleucel-T immunotherapy for castration-resistant prostate cancer. N Engl J Med. 2010;363:411-22. https://doi.org/10.1056/ NEJMoal001294

81. Gorchakov AA, Kulemzin SV, Kochneva GV, Taranin AV. Challenges and Prospects of Chimeric Antigen Receptor T-cell Therapy for Metastatic Prostate Cancer. Eur Urol. 2020;77:299-308. https:// doi.org/10.1016/j.eururo.2019.08.014

82. Sharma P, Pachynski RK, Narayan V, Flechon A, Gravis G, Galsky MD, et al. Nivolumab Plus Ipilimumab for Metastatic Castration-Resistant Prostate Cancer: Preliminary Analysis of Patients in the CheckMate 650 Trial. Cancer Cell. 2020;38:489-99 e3. https://doi.org/10.1016/j.ccell. 2020.08.007

83. Vikas P, Borcherding N, Chennamadhavuni A, Garje R. Therapeutic Potential of Combining PARP Inhibitor and Immunotherapy in Solid Tumors. Front Oncol. 2020;10:570. https://doi.org/10.3389/ fonc. 2020.00570

84. Garcia AJ, Ruscetti M, Arenzana TL, Tran LM, Bianci-Frias D, Sybert E, et al. Pten null prostate epithelium promotes localized myeloid-derived suppressor cell expansion and immune suppression during tumor initiation and progression. Mol Cell Biol. 2014;34:2017-28. https://doi.org/10.1128/ MCB.00090-14

85. Han HJ, Li YR, Roach M, 3rd, Aggarwal R. Dramatic response to combination pembrolizumab and radiation in metastatic castration resistant prostate cancer. Ther Adv Med Oncol. 2020;12:1758835920936084. https://doi.org/10.1177/1758835920936084

86. Marks L, Young S, Natarajan S. MRI-ultrasound fusion for guidance of targeted prostate biopsy. Curr Opin Urol. 2013;23:43-50. https://doi.org/10.1097/MOU.0b013e32835ad3ee

87. Songmen S, Nepal P, Olsavsky T, Sapire J. Axumin Positron Emission Tomography: Novel Agent for Prostate Cancer Biochemical Recurrence. J Clin Imaging Sci. 2019;9:49. https://doi.org/10.25259/ JCIS_139_2019

88. Kabasakal L, Demirci E, Nematyazar J, Akyel R, Razavi B, Ocak M, et al. The role of PSMA PET/CT imaging in restaging of prostate cancer patients with low prostate-specific antigen levels. Nucl Med Commun. 2017;38:149-55. https://doi.org/10.1097/MNM.0000000000000617 
89. Crawford ED, Petrylak DP, Shore N, Saad F, Slovin SF, Vogelzang NJ, et al. The Role of Therapeutic Layering in Optimizing Treatment for Patients With Castration-resistant Prostate Cancer (Prostate Cancer Radiographic Assessments for Detection of Advanced Recurrence II). Urology. 2017;104: 150-9. https://doi.org/10.1016/j.urology.2016.12.033

90. Crawford ED, Koo PJ, Shore N, Slovin SF, Concepcion RS, Freedland SJ, et al. A Clinician's Guide to Next Generation Imaging in Patients With Advanced Prostate Cancer (RADAR III). J Urol. 2019;201:682-92. https://doi.org/10.1016/j.juro.2018.05.164

91. El-Amm J, Aragon-Ching JB. Radium-223 for the treatment of castration-resistant prostate cancer. Onco Targets Ther. 2015;8:1103-9. https://doi.org/10.2147/OTT.S44291

92. Jones W, Griffiths K, Barata PC, Paller CJ. PSMA Theranostics: Review of the Current Status of PSMATargeted Imaging and Radioligand Therapy. Cancers (Basel). 2020;12. https://doi.org/10.3390/ cancers 12061367

93. Cook GJ, Azad G, Padhani AR. Bone imaging in prostate cancer: the evolving roles of nuclear medicine and radiology. Clin Transl Imaging. 2016;4:439-47. https://doi.org/10.1007/s40336-016-0196-5

94. Yu Z, Carlucci G, Ananias HJ, Dierckx RA, Liu S, Helfrich W, et al. Evaluation of a technetium-99m labeled bombesin homodimer for GRPR imaging in prostate cancer. Amino Acids. 2013;44:543-53. https://doi.org/10.1007/s00726-012-1369-9

95. Wong KK, Piert M. Dynamic bone imaging with 99mTc-labeled diphosphonates and 18F-NaF: mechanisms and applications. J Nucl Med. 2013;54:590-9. https://doi.org/10.2967/jnumed.112.114298

96. Filippi L, Basile P, Schillaci O, Bagni O. The Relationship Between Total Lesion Activity on (18)F Choline Positron Emission Tomography-Computed Tomography and Clinical Outcome in Patients with Castration-Resistant Prostate Cancer Bone Metastases Treated with (223)Radium. Cancer Biother Radiopharm. 2020;35:398-403. https://doi.org/10.1089/cbr.2019.3188

97. Wallitt KL, Khan SR, Dubash S, Tam HH, Khan S, Barwick TD. Clinical PET Imaging in Prostate Cancer. Radiographics. 2017;37:1512-36. https://doi.org/10.1148/rg.2017170035

98. Almeida FD, Yen CK, Scholz MC, Lam RY, Turner J, Bans LL, et al. Performance characteristics and relationship of PSA value/kinetics on carbon-11 acetate PET/CT imaging in biochemical relapse of prostate cancer. Am J Nucl Med Mol Imaging. 2017;7:1-11.

99. Heck MM, Tauber R, Schwaiger S, Retz M, D'Alessandria C, Maurer T, et al. Treatment Outcome, Toxicity, and Predictive Factors for Radioligand Therapy with (177)Lu-PSMA-I\&T in Metastatic Castration-resistant Prostate Cancer. Eur Urol. 2019;75:920-6. https://doi.org/10.1016/j.eururo. 2018.11.016

100. Morgenstern A, Apostolidis C, Kratochwil C, Sathekge M, Krolicki L, Bruchertseifer F. An Overview of Targeted Alpha Therapy with (225)Actinium and (213)Bismuth. Curr Radiopharm. 2018;11:200-8. https://doi.org/10.2174/1874471011666180502104524 